\title{
Managerial Skills: An Imperative for Business Education in Enhancing Nigerian Dwindling Economy
}

\author{
Lukman Suleiman ${ }^{1}$ \\ Mansur Saidu Adam² \\ Usman Dahiru Jibrin ${ }^{3}$ \\ Umar Buba ${ }^{4}$
}

\begin{abstract}
${ }^{1+2+3+4}$ Department of Vocational and Technology Education, Faculty of Technology Education, Abubakar
Tafawa Balewa University, Bauchi, Bauchi State, Nigeria.

Correspondence: Lukman Suleiman, Department of Vocational and Technology Education, Faculty of Technology Education, Abubakar Tafawa Balewa University, Bauchi, Bauchi State, Nigeria, Tel: + 07037714353, E-mail: karshal.rahuljaiswai@gmail.com
\end{abstract}

Received: September 21, 2017

Accepted: September 28, 2017

Online Published: October 2, 2017

\begin{abstract}
The main aim of this study is to determine the important of business education managerial skills in overcoming the problems of economic recession in Nigeria. Literature was extensively reviewed in relation to business education, managerial skills and economic recession, on that note the concept of business education was discussed by different literature. Furthermore, five (5) importance of business education were identified in relation to the economic development and the nation's dwindling economy. The study went further and identifies different kind of managerial skills needed by business education students, these skills were found to be very essential in promoting the Nigerian economy and also serves as a way of eradicating the dwindling economy of any given nation.
\end{abstract}

Keywords: Business Education, Managerial Skills, Dwindling Economy.

\section{Introduction}

Dwindling economy has a direct relationship with decline in wealth, consumption and business/managerial skills, along with government spending that represent the nation's economic engine. The National Bureau of Economic Research (NBER)defined dwindling economy as a significant decline in economic activity spread across the economy, which have a direct effect on real Gross Domestic Product (GDP), real income, employment, industrial production, wholesale and retail sales. Dwindling economy can also be seen as a negative real GDP growth rate in a country for two or more consecutive quarters. Judging by the above definitions, Nigeria is experiencing economic recession especially by the year 2016. However, the economy of Nigeria is appreciating towards the year ending of 2017 (Kale, Maigari, \& Haruna, 2017)

Business education as a discipline is expected to expose its recipients to diversity of skills needed in the world 
of work. Hence, it is the type of education that inculcates in its recipients attitudes, knowledge, skills and values that are required in the business world (Salome, 2012). This is a means of producing a healthy, literate self-reliant citizen that would create wealth for human development, when they become self-employed, thereby resulting to sustainable nation's development at large. Business education must have impacted managerial skills and creative knowledge required for employment generation opportunities, such skills and competences that would also make the business graduates to adopt some strategic survival drives.

According to (Ibrahim, 2014) managerial skills are those essential skills that are needed to get most jobs that are helpful to employees to stay in a job and facilitate their promotions. The skills are flexibly adapted, applied and transferred under different contexts necessary for gainful employment. According to Halliru (2011) managerial skills include technical skills, human relation skills, conceptual skills, design skills, Critical Thinking and Judgments Skills, Skills in Solving complex, multidisciplinary and open-ended problems, Creativity and entrepreneurial thinking Skills, Communicating and collaborating Skills, Skills in Making innovative use of knowledge, information and opportunities and Skills in taking charge of financial health and civic responsibilities. The framework of managerial skills of Senior (2009) indicated that, a good curriculum should provide students with skills on effective communication; supervision; coordinating; planning and think strategically, with clear vision, information and communication. To this end, business education skills are very essential that if properly acquired and utilize would go a long way in improving the employment opportunities of the youths and also mitigate the level of Nigerian dwindling economy.

\section{Concept of Business education}

Business education is an essential ingredient of vocational education. In Nigeria, the education is offered at both the secondary and tertiary institutions of learning. According to Abdullahi (2002) Business education is an aspect of educational programme which provides the recipients with knowledge, skills, understanding and attitude needed to perform well in the business world as a producer or consumer of goods and services. Furthermore, Osuala (2004) is of the opinion that Business education is a broad area of knowledge that deals with a nation's economic system and also identifies and explains the rate of business contentment and experience that prepare individuals for effective participation as citizens, workers and consumers. The National Open University of Nigeria (NOUN) (2008) defines Business education as an aspect of vocational education that equips people with necessary skills and theoretical knowledge needed for performance in business world either for job occupation or self-employment.

Finally, Aliyu (2013) stated that the purpose of Business education is to stress the need for fundamental instruction to help students assume their economic roles as consumers, workers and citizens in boosting the nation's economy, providing specialized instruction to prepare students with necessary skills for career in business. It can be deduced from the definitions above that Business education is an education for and about business. It combines both theoretical knowledge and practical skills needed in the work place. In the same vein, it exposes the recipients to the economic system of their country and equips them with lifelong skills that would enable them to make reasonable judgement as a producers (entrepreneurs), employees or consumers of goods and services.

\section{Importance of Business Education to the Nigerian Economy}

The importance of business education to the Nigerian economy will never be over emphasized, however, Emmanuel, Omotayo, and Tuke (2015) pointed out some of the importance of business education in enhancing the nation's economy as follows: 
- Business Education is important to the nation in providing skills that enables them to become employers of labour, so that people become job creators and over-dependence on government work would also minimize.

- Business education develops proper values towards work as they contribute more to the economic development of the nation by providing the required skills needed by handicrafts men and women which lead them to become self-reliant.

- Business education provides its recipients with the skills that if properly utilize they can spend their resources judiciously which in turn the country gains by way of investing excess resources on meaningful projects that would lead to economic development. Today, we are talking about economic recession and rate of inflation, this can be minimize if we spend wisely.

- Business education has made it possible for those who want to be retrained in order to upgrade their skills and have access to education. In this way, people who finish secondary school with no saleable skills will have to acquire skills that make them become functional, through retraining programmes.

- Business education prepares its recipients for the world of work, they can either take up teaching profession or they become business people.

\section{Managerial Skills Needed by Business Education}

Management is an aspect of business education that provide the students with managerial functions, skills and other business related talents that will help them to work effectively in an organization. Literatures comes up with different types of management skills needed by business education that will serve as a route in ensuring the nation's economic growth and development so that the Nigerian dwindling economy would be eradicated. Nazir (2010) said that leadership Skills is the management skills that require business education to set-up priorities, delegate, motivate, coach and develop your people to become top performers and communicate objectives and goals of the organisation. Salome (2012) further emphasized that the skill comes from the knowledge of and proficiency in activities involving methods, procedures and processes of getting thing done. To this end the skills involve efficiency in dealing with subordinate, working with tools, techniques and equipment to coordinate the activities of the organization to perform as expected.

Communication skills is the skill that require the manager to get points across by creating a compelling presentation to support goals and get buy-in for ideas, inspire others to achieve better results and demonstrate emotional intelligence (Nwanaka \& Samuel, 2011). In a similar view, Riebe, Girardi, and Whitsed (2016) reiterated that communication skills are the capability to express information to another person effectively and efficiently. Thus, the skills can be verbal or non-verbal, written or unwritten means of communication that facilitate the sharing of information between two or more people in an organization.

Human Relation Skills is the management skills that involve the ability to work with people (Ibrahim, 2014). This involves cooperating with one another as a team by creating an environment when people feel secured and free to express their opinions. Collaboration skills are the managers' commitment to form alliances and negotiate effectively (Okolie. 2014). Nazir, (2010) further said that collaborative skills are a skill that involves working together with other people through idea sharing and thinking to accomplish a common goal. Developing and encouraging collaborative skills in workplace is likely to enhance team commitment and individual performance, which might result in minimizing the Nigerian dwindling economy.

Robles (2012) said that conceptual skill is the ability to see the big picture of the ends in view (objective) of where you are going. It also demands that you should be able to see those activities that are necessary to realize 
the big picture of the organization, the picture must be clear, capable of supervising and monitoring the activities of employees, customers and the management in order to improve the efficiency of the organization and increase employability in the nation.

According to Riebe, Girardi, and Whitsed (2016) critical thinking skills involves the managers' ability to approach problem solving logically, research options, avoid biases and focus on meaningful data to draw the right conclusions even under pressure. The skills empower managers to assess the credibility, accuracy and value of information, analyse and evaluate information, make reasoned decisions and take purposeful action. This will help in developing a clear and core effective thinking in promoting the image of businesses in Nigeria. Design skill is the ability of manager to solve problems associated with how to combine colour, graphics, technology, text, ideas and other relevant ingredients to come up with a product which will benefit the organization, customers and the nation at large (Snyder, 2013). This can open a way to job creation and also reduce the inflation rate in the country.

Finance skill is the capability to weigh different types of currencies implications of business in making decisions, including the ability to build a sound budget and formulate reasonable forecasts. It involves taking charge of financial, health and civic responsibilities and making wise choices by deciding how to invest their savings (Halliru, 2011). The basic skills needed to accurately predict revenues and unit costs of product is a helping matter in determining the average number of labour needed to employ (Ibrahim, 2014). Nigerians need more specialized financial skills simply because appropriate resource allocation requires critical thinking that favour marketplace and the Nigerian economy at large, this can reduce the over dependence on government work.

Okolie, (2014)said that to grasp the scope and objectives of any given projects, the manager must acquire the project management skills, this will help to recognize the roles and responsibilities of others. The manager will use tools to stay on track and become an effective member of a cross-functional team. In that building a social foundation of project management knowledge and techniques will cover the entire project life cycle.

Creativity and entrepreneurial thinking skill is a skill that is highly demanded to boost the Nigerian economy. It is highly associated with job creation, many of the fastest-growing jobs and emerging industries rely on workers' creative capacity and the ability to think unconventionally in creating something new (Sikorski, 2007). The global marketplace rewards organizations that rapidly and routinely find better ways of doing things. Likewise, Nigerians can create jobs for themselves and others with an entrepreneurial mind-set to recognize and act on opportunities and the willingness to embrace risk and responsibility for the nation's economic growth.

\section{Conclusion}

This study stressed the need for minimizing the ongoing economic recession in Nigeria, fundamentally there is urgent need to inculcate managerial skills in the curriculum of business education at all levels, this would help the students acquire some skills which in turn enables them to assume their economic roles as consumers, workers and citizens in boosting the nation's economy. It is however noticed that business education is an umbrella term in providing these types of skills. The skills are very essential that if properly acquired and utilized would go a long way in improving the employment opportunities of the youths and also mitigate the level of the Nigerian dwindling economy.

It can be deduced that Business education is an education for and about business, it combines both theoretical knowledge and practical skills needed in the work place. In the same vein, it exposes the recipients to the economic system of a country and equips them with life-long skills that would enable them to make reasonable judgement as a producer, employee or consumer of goods and services. To this end, The importance of business 
education managerial skills to Nigerian economy will never be over emphasize, the study concludes that to mitigate the economic recession in Nigeria, many literature come to realized that utilization of managerial skills have a significant impact in enhancing the nation's economy

\section{Recommendation}

The following recommendations were raised

- There should be a provision for periodic retraining of business education teachers to update their knowledge in the various areas of management skills. This will expose them to modern trends in management across the globe and contribute to the nation's economy.

- Business education teachers should re-dedicate themselves by attending more workshops and seminars to acquaint themselves with these skills so that they can in turn, impart same in the students.

- The higher institutions should emphasis on curriculum that is aimed at improving skills and expanding the production of management professionals in the country.

- Management education should become a main-stream activity in education to enable transformations of Nigerian economic growth and development.

\section{References}

Abdullahi A. (2002). Business Education, Technology and National Development. . Book of Reading in Business Education, 1(2), 1-5.

Aliyu, M. M. (2013). Subject method for business teachers. Kaduna: Sunjo A.J. Global Limited.

Emmanuel, A. O., Omotayo, B. K., \& Tuke, E. (2015). Issues in Business Education Programme: Challenges to National Transformation. Journal of Education and Practice, 6(21).

Halliru, A. J. (2011). Business Education Managerial Skills For National Development. International Jornal of Business Education, 2(7), 23-25.

Ibrahim, A. (2014). Assesment Of Adequacy Of Business Education Curriculum Content On University Students Acquisition of Requisite Skills For Job Opportunities In Nigeria.

Kale, A., Maigari, B., \& Haruna, H. (2017). Economic Recession in Nigeria: Implications for Nursing Education and Practice. IOSR Journal of Nursing and Health Science, 06(02), 54-62. doi: 10.9790/1959-0602095462

National Open University of Nigeria. (2008). Business education methods. Lagos: National Open University of Nigeria.

Nazir, M. (2010). Problem-Based Learning On Students"e Critical Thinking Skills In Teaching Business Education. . American Journal of Business Education, 3(6).

Nwanaka C. R, \& Samuel, A. (2011). Skills Acquisition: Imperative For Business Studies Educators Among Secondary Schools In Rivers State. Mediterranean Journal of Social Sciences, 2(7).

Salome, E. N. (2012). The Teacher and Skills Acquisition at Business Education: From the Perspective of Aacounting Skills. Arabian Journal of Business and Management Review, 2(4).

Okolie, U. C., (2014). Influence of Entrepreneurship Education on Students Attaining Business Development Awareness and Skills Acquisition in Nigeria. Journal of Research \& Method in Education, 4(3), 37-44.

Osuala, E. C. (2004). Foundation of vocational education, (5th ed).Enugu: Cheston Agency Ltd.

Robles, M. M. (2012). Executive Perceptions of the Top 10 Soft Skills Needed in Today's Workplace. Business Communication Quarterly, 75(4), 453-465. doi:10.1177/1080569912460400 
Managerial Skills: An Imperative for Business Education in Enhancing Nigerian Dwindling Economy

Lukman et al.

Riebe, L., Girardi, A., \& Whitsed, C. (2016). Teaching Teamwork Skills in Australian Higher Education Business Disciplines: Teaching and Learning Forum.

Senior Z. (2009). Challenges of labour market on graduates in 21st century: Unpublished.

Sikorski A. (2007). Why Career Development, From http://www.lehigh.edu/ Retrieved on 4/12/2011.

Snyder, M. J. (2013). Teaching Critical Thinking and Problem Solving Skills.

\section{Copyrights}

Copyright for this article is retained by the author(s), with first publication rights granted to the journal. 